\title{
Granulosa cell tumor of the ovary: a clinicopathological study of six cases
}

\author{
Adhikari $\mathrm{RC}^{1}$, Jha $\mathrm{A}^{1}$, Shayami $\mathrm{G}^{1}$ \\ ${ }^{1}$ Department of Pathology, Tribhuvan University Teaching Hospital, Institue of Medicine, Kathmandu, Nepal
}

\section{Keywords: \\ Granulosa cell tumor; \\ Ovary; \\ Histopathological \\ findings}

\begin{abstract}
Background: Ovarian granulosa cell tumors are rare malignant neoplasms that originate from the sexcord stromal cells of the ovary. The study aims to collate data of all granulosa cell tumors diagnosed in Tribhuvan University Teaching Hospital over the last 3 years and to describe the incidence, patient profile, ultrasonographic and histopathologic findings in our local context.
\end{abstract}

Materials and Methods: A total of $6(5 \%)$ granulosa cell tumors, diagnosed in Tribhuvan University Teaching Hospital during the period from April 2008 to March 2011. The patient's age, symptoms, radiological findings, type of surgery performed, tumor size and follow-up status were evaluated.

Results: All 6 patients were diagnosed as adult granulosa cell tumor, three of which were postmenopausal $(50 \%)$ and remaining there was premenopausal. The symptoms recorded were uterine bleeding, abdominal pain, distention and mass. Grossly, in 3 cases granulosa cell tumors were solid and firm, in 2 cases solid and cystic and 1 case is predominantly cystic. Histologically, variety of patterns including diffuse, trabecular, cords, tubular, nesting and Call-Exner bodies were found. Nuclear grooves were observed in all cases. Follow up on 2 patients revealed no evidence of recurrence.

Conclusion: This study supports the view that most granulosa cell tumors are diagnosed in stage I and there is good correlation between radiological and gross findings in terms of tumor size and solid or cystic status.

\section{INTRODUCTION}

Ovarian granulosa cell tumor (GCT) is a rare malignant neoplasm that originates from the sex-cord stromal cells of the ovary and represent $2 \%$ to $5 \%$ of all ovarian cancers. ${ }^{1,2}$ They are classified under the category of sex-cord stromal tumors: juvenile or adult type. ${ }^{3}$ Juvenile GCT represents only $5 \%$ of this tumor and usually occurs in prepubertal

\section{Correspondence:}

Dr. Ram Chandra Adhikari, $M D$

Associate professor, Department of Pathology, Tribhuvan University Teaching Hospital, Institue of Medicine, maharajgunj, Kathmandu, Nepal E-mail:rcadhikari@hotmail.com girls and women younger than 30 years., ${ }^{4,5}$ The majority of women with adult GCTs present with early stage disease. The neoplasm is characterized by a slow growth, relatively low malignant potential and late recurrence., ${ }^{2,6}$ There are many factors that influence the prognosis; such as stage at presentation, age, tumor size and histological staging. ${ }^{7}$ The treatment modalities include surgical management, chemotherapy and radiotherapy depending on tumor stage. Patients with GCT, irrespective of age and type of surgery performed, require observation indefinitely. ${ }^{8}$ 
TABLE 1: A profile of patients with adult granulosa cell tumor

\begin{tabular}{|c|c|c|c|c|c|c|}
\hline Case no. & Age (yr) & Parity & Menopausal status & Endometrial histology & Surgery & Stage \\
\hline 1 & 27 & 1 & Premenopausal & Not available & $\mathrm{RSO}^{*}$ & $1 \mathrm{~A}$ \\
\hline 2 & 36 & 2 & Premenopausal & Proliferative & $\mathrm{LSO}^{\S}$ & $1 \mathrm{~A}$ \\
\hline 3 & 19 & 0 & Premenopausal & Not available & LSO & $1 \mathrm{~A}$ \\
\hline 4 & 80 & 6 & Postmenopausal & Not available & TAH with BSO & $1 \mathrm{~A}$ \\
\hline 5 & 64 & 3 & Postmenopausal & Inactive & TAH with BSO & $1 \mathrm{~A}$ \\
\hline 6 & 72 & 3 & Postmenopausal & Hyperplasia & TAH with BSO & $1 \mathrm{~A}$ \\
\hline
\end{tabular}

The study aims to collate data of all granulosa cell tumors diagnosed in Tribhuvan University Teaching Hospital (TUTH) over the last 3 years and to corelate with histopathologic findings.

\section{MATERIALS AND METHODS}

During the period from April 2008 to March 2011, all the necessary data were retrieved from department of pathology, TUTH who were diagnosed as GCT. There were a total of 120 ovarian malignancies, diagnosed in TUTH over this 3-year period, of which 6 (5\%) were GCT. Clinical findings, treatment and follow-up data were reviewed from the medical records. The patient's age, symptoms, radiological

findings, type of surgery performed, tumor size and followup status were evaluated.

\section{RESULTS}

The mean age at diagnosis of GCT was 49.6 years with a range of 19 to 80 years. All 6 patients were diagnosed as adult GCT. The patient profile of these 6 cases is summarized in the table 1 .

All patients were symptomatic with complaints of uterine bleeding, abdominal pain, abdominal distention and mass. Four patients presented with abnormal uterine bleeding and 2 patients with abdominal mass, in one of which emergency laporatomy was performed due to twisting of the ovary. Ascites and signs of distant metastasis were not noted.

Serum CA 125 was done in 5 cases, and ranges from 4.1 to $55 \mathrm{IU} / \mathrm{ml}$ (normal: $0-35 \mathrm{IU} / \mathrm{ml}$ ). CEA was done in 2 cases and found to be normal.

Of the 6 patients, 3 underwent unilateral salpingooophorectomy and/or omentectomy, while remaining 3 patients underwent total abdominal hysterectomy with bilateral salpingo-oophorectomy and omentectomy. Endometrial histology showed simple hyperplasia without atypia in one case and proliferative endometrium in 2 cases.

All patients underwent ultrasonography (USG) that revealed hypoechoic solid to cystic mass with a size ranging from 7 $\mathrm{cm}$ to $16 \mathrm{~cm}$. In 2 cases, the USG revealed both solid and cystic area within the mass. The ultrasonographic tumor size correlated well to the tumor size measured grossly. In 2 cases, computed tomography was performed and revealed solid malignant ovarian mass.

The mean tumor size was $10.9 \mathrm{~cm}$ with a range of 7.5 to $15 \mathrm{~cm}$. The tumor was unilateral and limited to ovary in all cases. Ovarian capsule, fallopian tube and omentum were free of tumor in all cases. Grossly, in 3 cases GCTs were solid and firm, in 2 cases solid and cystic and 1 case is predominantly cystic. Histologically, variety of patterns including diffuse (fig.1), trabecular (fig.2), cords \& strands (fig.3), tubular, nesting were noted and Call-Exner bodies

were found in 1 case. Nuclear grooves (fig.4) were observed in all cases.

Chemotherapy or radiotherapy was not given. Follow up on 2 patients revealed no evidence of recurrence.

\section{DISCUSSION}

Adult GCTs of the ovary are rare neoplasm and it constituted $5 \%$ of all ovarian malignancies in this study. GCT can occur at any age but most commonly presents during the perimenopausal or early postmenopausal period with median age of diagnosis between 50 and 54 years in most series. ${ }^{2,4,5,9,10}$ In this study, the mean age is 49.6 year and $50 \%$ patients were postmenopausal.

Patients with GCT may present with abdominal pain, mass, uterine bleeding, abdominal distention and amenorrhoea. ${ }^{11}$ In this study, most of the patients presented with abnormal uterine bleeding and others with abdominal mass, distention or pain.

The neoplasm is divided into adult and juvenile types, based on different clinical and histopathologic features. Juvenile form tends to occur during the first three decades of life and is associated with a common form of isosexual pseudoprecocity. ${ }^{3}$

Hormone production is frequent and approximately $25 \%$ to $50 \%$ of GCTs are associated with endometrial hyperplasia 
and $5 \%$ to $13 \%$ with endometrial carcinoma. ${ }^{2,9,10}$ In this study, only 1 patient (16.6\%) showed endometrial hyperplasia.

Tumor markers of this neoplasm are estradiol, inhibin, follicle regulatory protein and mullerian inhibitory substance. ${ }^{12}$ None of these markers were estimated in our study; instead CA 125 and CEA were done. CA 125 was mildly elevated in 2 patients.

Imaging findings in adult GCT vary widely and range from solid masses to tumors with varying degree of hemorrhagic or fibrotic changes, to multilocular cystic lesions to completely cystic tumors. ${ }^{8}$ In this study, 5 patients had solid ovarian mass and the tumor is solid and cystic in one case.

The gross appearance of GCT varies greatly. They are solid, soft or firm to predominantly cystic and sometimes may resemble mucinous cystadenoma. ${ }^{8}$ Majority of these tumors is of substantial size (more than $8 \mathrm{~cm}$ ) at the time of presentation, averaging $11.9 \mathrm{~cm}$ in the Norris series ${ }^{14}, 9.3$ $\mathrm{cm}$ in the chua series ${ }^{15}$, as compared to $10.9 \mathrm{~cm}$ in this study.

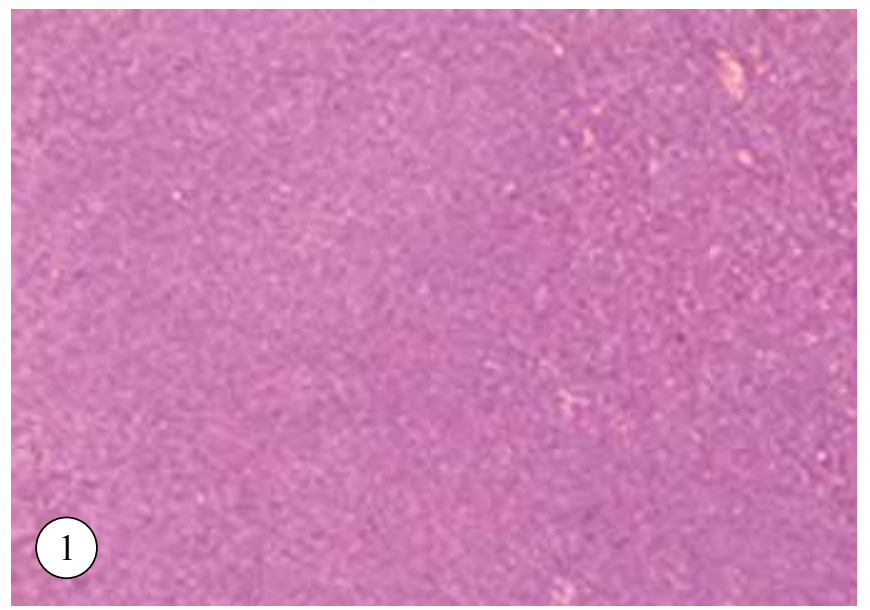

Figure 1: GCT, Diffuse pattern (HE stain, X100)

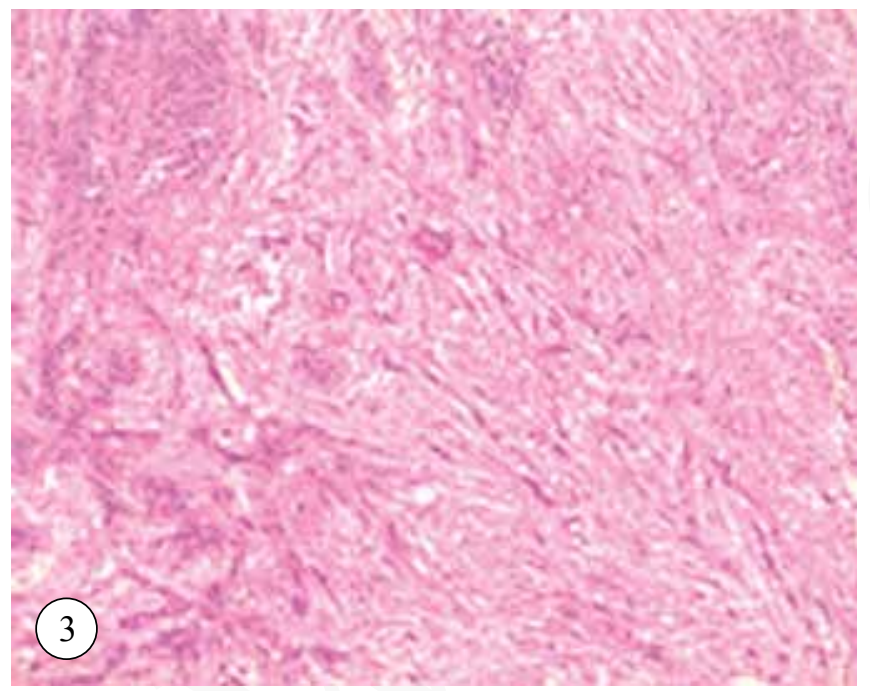

Figure 3: GCT, Strands of tumor with infiltrating pattern.

(HE stain, X100)
GCT can be well or moderately differentiated and all our cases were well differentiated. The variety of patterns including microfollicular, trabecular, solid, tubular, diffuse and water-silk are observed in GCT. ${ }^{12}$ We also observed variety of patterns. Differential diagnoses include undifferentiated carcinoma, adenocarcinoma and carcinoid. Call-Exner bodies and nuclear grooves are important diagnostic features of GCT.

All cases were diagnosed in stage I in this study as in the large published studies, in which upto $78-91 \%$ of tumors are diagnosed in stage $\mathrm{I}^{15}$

The surgical procedure for patients with GCT has traditionally been similar to that used for epithelial ovarian cancer. In a young patient desiring to preserve fertility, unilateral salpingo-ooophorectomy should be performed and a total abdominal hysterectomy with bilateral salpingo-ooophorectomy should be performed for patients whose fertility is not an issue and for postmenopausal

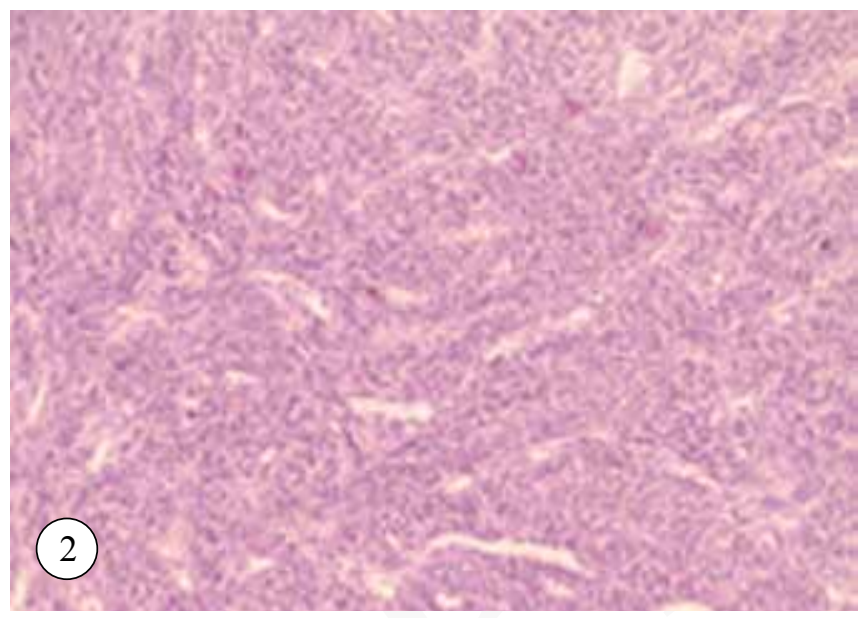

Figure 2: GCT, Trabecular pattern (HE stain, X100)

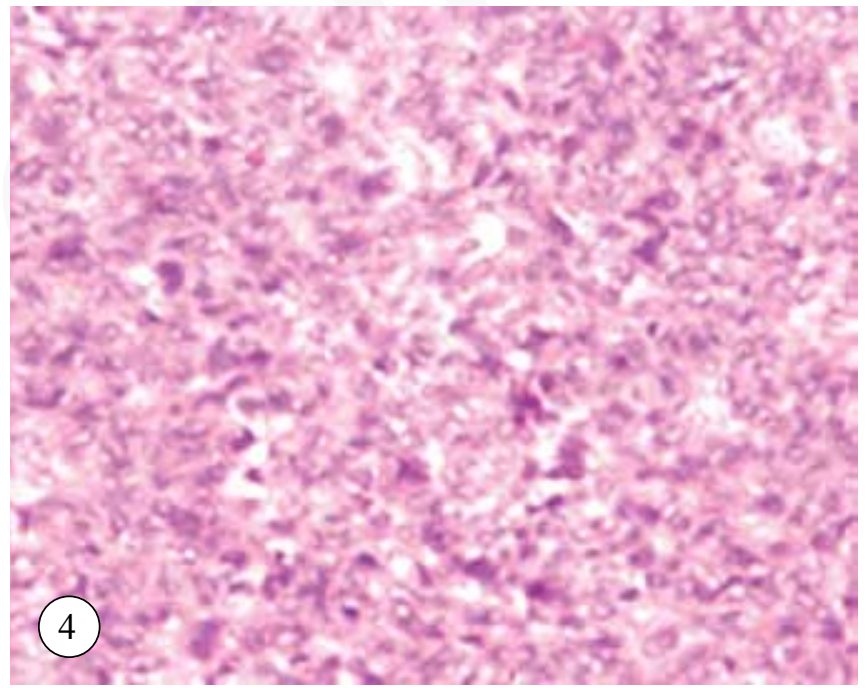

Figure 4: GCT, highlighting nuclear grooves (HE stain, X400) 
women. ${ }^{12}$ Omentectomy is also performed. In our study, total abdominal hysterectomy with bilateral salpingoooophorectomy was performed in 3 patients and unilateral salpingo-ooophorectomy in 3 young patients. Radiation therapy has been used in adjuvant setting or for recurrent disease. In patients with stage I disease, the prognosis is excellent, with the long-term disease free survival rate said to be about $90 \%$ and no further treatment is required after surgery. ${ }^{2,12,16}$ All our patients were diagnosed at stage I, no further chemotherapy or radiotherapy were given after surgery.

The 5-year survival of stage I GCT is $90-100 \%{ }^{7,16,17}$ In our study, most of the patients were lost to follow up and 2 patients showed no evidence of disease recurrence on follow-up.

\section{CONCLUSION}

Most GCTs are diagnosed in stage I even in developing countries like Nepal. Despite the small number of patients, the study showed good correlation between radiological and gross findings in terms of tumor size and solid cystic status.

\section{REFERENCES}

1. Schumer ST, Cannistra SA. Granulosa cell tumor of the ovary. J Clin Oncol 2003;21:1180-9.

2. Evans AT III, Gaffey TA, Malkasian GD Jr, Annegers JF. Clinicopathologic review of 118 granulosa and 82 theca cell tumors. Obstet Gynecol 1980;55:231-8.

3. Segal R, DePetrillo AD, Thomas G. Clinical review of adult granulosa cell tumors of the ovary. Gynaecol Oncol 1995;56: 338-44.

4. Young RH, Dickersin GR, Scully RE. Juvenile granulosa cell tumors of the ovary: A clinicopathologic analysis of 125 cases. Am J surg Pathol 1984;8:575-96.
5. Scully RE. Juvenile granulosa cell tumor. Pediatr Pathol 1988;8:4237.

6. Colombo N, Sessa C, Landoni F, Sartori E, Pecorelli S, Mangioni C. Cisplatin, vinblastine and bleomycin combination chemotherapy in metastatic granulosa cell tumor of the ovary. Obstet Gynecol 1986;67:265-8.

7. Schwartz PE, Smith JP. Treatment of ovarian stromal tumors. Am J Obstet Gynecol 1981;11:261-74.

8. Pectasides D, Pectasides E, Psyrri A. Tumor review, granulosa cell tumors of the ovary. Cancer treatment reviews 2008;34:1-12

9. Fox H, Agrawal K, Langley FA. A clinicopathologic study of 92 cases of granulosa cell tumor of the ovary with special reference to the factors influencing prognosis. Cancer 1975:35:231-41.

10. Malmstrom H, Hogberg T, Risberg B, Simonsen E. Granulosa cell tumors of the ovary: prognostic factors and outcome. Gynecol Oncol 1994;52:50-5.

11. Uygun K, Aydiner A, Saip P et al. Granulosa tumor of the ovary: retrospective analysis of 45 cases. Am J Clin Oncol 2003;26:517-21.

12. Koukourakis GV, Kouloulias VE, Koukourakis MJ et al. Granulosa cell tumor of the ovary: tumor review. Integr Cancer Ther 2008;7:20415 .

13. Norris HJ, Zaloudek C. Granulosa cell tumors of the ovary: a clinical and pathologic study of 32 cases. Am J Surg Pathol 1984;6:405.

14. Chua ISY, Tan KT, Lim-Tan SK, Ho TH. A clinical review of granulosa cell tumors of the ovary cases in KKH. Singapore Med J 2000;42:203-7.

15. Hines JF, Khalifa MA, Moore JL, Fine KP, Lage JM, Barnes WA. Recurrent granulosa cell tumor of the ovary 37 years after initial diagnosis: A case report and review of the literature. Gynaecol Oncol 1996;60:484-8.

16. Savage P, Constenla D, Fisher C et al. Granulosa cell tumors of the ovary: demographics, survival and the management of advanced disease. Clin Oncol 1998;10:242-5.

17. Bjorkholm E, Silfversward C. Prognostic factors in granulosa cell tumors. Gynecol oncol 1981;11:261-74. 